\title{
Chapter 2 \\ Conceptualizing the Meaning, Theory, and Practice of Learning Societies \\ During an Age of Disruption
}

\author{
Rupert Maclean and Leone Wheeler
}

\section{Abbreviations}

$\begin{array}{ll}\text { ADB } & \text { Asian Development Bank } \\ \text { ALE } & \begin{array}{l}\text { adult learning education } \\ \text { coronavirus disease }\end{array} \\ \text { COVID-19 } & \begin{array}{l}\text { gross domestic product } \\ \text { GDP }\end{array} \\ \text { GNLC } & \text { Global Network of Learning Cities } \\ \text { OECD } & \text { Organisation for Economic Co-operation and Development } \\ \text { SMEs } & \text { small and medium-sized enterprises } \\ \text { TVET } & \text { technical and vocational education and training } \\ \text { UIL } & \text { UNESCO Institute for Lifelong Learning } \\ \text { UNESCO } & \text { United Nations Educational, Scientific and Cultural Organization } \\ \text { WEF } & \text { World Economic Forum }\end{array}$

\subsection{Introduction}

The concept "learning society" can be traced back to ancient Greece in the West, and to Confucius in the East (Longworth and Osborne 2010; Yiannouka 2020). There

R. Maclean ( $\varangle)$

School of Education, RMIT University, Melbourne, Australia

e-mail: rupert.maclean@utas.edu.au

School of Education, University of Tasmania, Hobart, Tasmania, Australia

L. Wheeler

School of Global, Urban and Social Studies, RMIT University, Melbourne, Australia

e-mail: leone.wheeler@rmit.edu.au 
has been a modern re-emergence and renewed interest and focus on the learning society since the later part of the twentieth century, based on changing notions of learning, which go beyond the conventional distinction between the formal sectors of education and continuing education, to embrace lifelong learning and learning throughout life (Longworth and Osborne 2010).

Two key reports commissioned by the United Nations Educational, Scientific and Cultural Organization (UNESCO) have been important catalysts for renewed thinking on the meaning of learning society in modern times. The first is Learning to Be: The World of Education Today and Tomorrow (Faure et al. 1972). Known as the Faure Report, it proposed that lifelong education is a "master concept" at the heart of learning societies (Elfert 2015). The second report, Learning: The Treasure Within (Delors et al. 1996), commonly known as the Delors Report, highlighted the importance of learning throughout life through its "four pillars of learning."

Both reports continue to influence education scholars, policy makers, and practitioners to this day. For example, Robbie Guevara, who is President of the International Council of Adult Education, and a Board Member of the Global Campaign for Education representing Asia and the Pacific, applied a learning society framework to the coronavirus disease (COVID-19) pandemic (Guevara 2020). He reworked the Delors Report's four pillars of learning and added a fifth pillar, "learning to transform oneself and society" previously developed by UNESCO in 2015 as part of the Education for Sustainable Development (Samantekt 2015).

\subsubsection{Learnability and Lifelong Learning}

The enhanced Delors framework demonstrates the importance of learnability of the individual or learning to learn - the skills that can be applied to the collective (i.e., the workplace and education systems); the family; the community; the importance of civil society; and caring for our world. Previously, the Delors framework was applied by various researchers to employability, work, and skills in the twenty-first century while others have applied it to learning communities, learning cities, and learning societies (Maclean and Ordonez 2007, Faris 2008, Kearns 2015, Wheeler et al. 2013). The Delors framework speaks of the "next normal" instead of the "new normal" since going into the future, we will be in a constant state of change and adaptability.

Learnability is a critical feature of ensuring that learners in schools, training institutions, universities, and other settings become capable of keeping pace with change, adapting to emerging needs of the economy and society, and navigating their lives in a productive manner. Longevity is an important aspect of a learning society since people are living longer and remaining as productive members of the labor force much longer. There is therefore an increasing need for them to be effective participants in lifelong learning for a longer period, for them to be fully contributing members to a learning society. 
This learnability can be applied to knowledge, skills, attitudes, and values required to cope with a health pandemic such as COVID-19. It could also be applied for other risks such as climate change.

There is a growing recognition of the importance of the concept of lifelong learning to support economic, social, environmental, and healthy futures for people and places. In this time of pandemic crisis, conflicts, and widening inequality gaps, international organizations such as the Asian Development Bank (ADB), International Labour Organization, Organisation for Economic Co-operation and Development (OECD), and UNESCO are placing an increasing emphasis on the importance of the concept of a learning society and lifelong learning. In the case of UNESCO, through its Future of Education: Learning to Become project, it is building on the ideas of key reports such as Faure et al. (1972) and Delors et al. (1996), and imagining a more just society, one where every person has the capacity to imagine a "good and fulfilling life" (UNESCO 2020). Indeed, a recent policy briefing on education in the time of COVID-19 by the Secretary-General of the United Nations (UN), António Guterres, makes it clear that it is imperative for national and international communities to come together to ensure that education is at the forefront of recovery agendas (UN 2020). It is vital to protect investment in education otherwise countries are likely to face a "generational catastrophe" that could undermine decades of progress, waste untold human potential, and worsen entrenched inequalities (UN 2020). While this UN policy briefing focuses on the formal education system, it is vital also to consider the learning society ecosystem that surrounds the individual learner.

\subsubsection{Learning Cities, Learning Communities, and Learning Regions}

The terms learning cities, learning communities, and learning regions are now commonly used and are models within a larger notion of a learning society (Longworth and Osborne 2010). Driven by formation of the UNESCO Global Network of Learning Cities (GNLC) in 2013, and the PASCAL International Observatory's Learning City Network, the Learning Cities movement has achieved great traction. There are now 230 member cities from 64 countries that are part of the GNLC, ${ }^{1}$ including 72 cities from the broader Asia and Pacific region, the majority (50) being from the Republic of Korea; nine cities in the People's Republic of China; three each in Australia and Thailand; two each in Japan and Viet Nam; and one each in Indonesia, Malaysia, and the Philippines. Thailand is currently considering establishing "learning cities for a post-COVID-19 era" in 20 provinces (Omas 2020).

\footnotetext{
${ }^{1}$ See UIL. Members of the UNESCO Global Network of Learning Cities. https://uil.unesco.org/ sites/default/files/doc/lifelong-learning/cities/list-of-members-unesco-gnlc-uil.pdf. The cities as of 2020 are listed at Pascal International Observatory. The UNESCO Global Network of Learning Cities welcomes 55 new member cities from 27 countries. http://pascalobservatory.org/pascalnow/ pascal-activities/news/unesco-global-network-learning-cities-welcomes-55-new-member-cities.
} 
While the learning cities development is important work, and partnerships and networks have been built that have proven to be particularly critical for international dialogue in this time of COVID-19, more remains to be done. As Kearns (2015) notes, this approach must be extended to rural areas in Africa, Asia, and elsewhere, including exploring the potential of the learning region concept in fostering innovative forms of partnership in rural and regional areas. Citizens in rural areas should have access to inclusive, high-quality learning opportunities that meet their future needs. The UNESCO Institute for Lifelong Learning (UIL) recognizes that the principles and values identified as key features of learning cities (UNESCO UIL 2015) are also applicable to those people living in rural and remote areas, in disadvantaged and poor neighborhoods and communities, as well as in small towns and villages under the umbrella of a learning society.

\subsubsection{The Learning Society}

In the past, place-based models founded on lifelong learning and the learning society have been harnessed to address a myriad of economic and social challenges, such as urbanization, demographic shifts, climate change, unemployment, migration, financial crises, threats to peace and security, and globalization. The Republic of Korea, Japan, and Singapore are examples of countries in the broader Asia and Pacific region that have applied the learning society approach to meet such challenges at the national level (Yang and Yorozu 2015).

In its 2020 meeting, the World Economic Forum (WEF 2020b) noted the massive economic and social realignment occurring due to globalization, and global risks such as climate change. The WEF also noted the economic and technological disruptions on work from rapidly changing information technology, as well as the effects of the fourth industrial revolution (Industry 4.0) and artificial intelligence (AI), which contribute to high unemployment and skills deficits. Societal trends such as involuntary migration, the ever-widening gap between rich and poor, and situations of conflict are continuing to impact the way people live, the way they learn, and how they are employed (Wood 2020).

The health emergency brought about by the COVID-19 pandemic has unleashed an unprecedented global crisis that is having a profound effect on societies and communities in multiple ways for which few are prepared (Magnuson 2020). Communities are living with disruption as a part of daily life and having to adapt quickly. The current health pandemic is a clear example of a disruption within a concentrated timeframe, is interconnected, and on a global scale, marked by the following short-term consequences:

(i) overstretched health systems,

(ii) weakened populations,

(iii) rising death rates,

(iv) rising unemployment rate, 
(v) impact on school systems and a consequent rise in the number of young people not in education or training, and

(vi) businesses and small and medium-sized enterprises (SMEs) having to limit trading or close.

In addition, there is the disproportionate effect on the poor, who generally live in more densely populated areas where, because of overcrowding, it is more difficult for them to follow recommendations for self-isolation and social distancing. The virus is impacting densely populated urban areas much more than rural areas.

\subsection{The Age of Disruption: Powering the Learning Society}

There are a multitude of challenges facing communities, the future of work, the sustainability of communities, and ultimately the planet. The economy, rapidly changing technology, the environment, climate change, conflict and terrorism, and now a pandemic are all major disruptors (Harari 2015; OECD 2020a; World Bank 2020a; WEF 2020a). These interlocking crises in climate, ecological, economic, social (including health and geopolitical areas of conflict), have highlighted both the vulnerability and resilience of our societies to such shocks (GIM 2020). The disruption of the job market, growing social and economic inequality, climate change, and the pandemic loom large.

\subsubsection{The Fourth Industrial Revolution or Industry 4.0}

The OECD surmises that Industry 4.0 is the "next production revolution" and will be the convergence of many new technologies including human-machine integration (supported by system integration and the Internet of Things), autonomous machines (supported by AI and cloud computing), and additive manufacturing cum 3D printing (supported by simulations and Big Data) (Envirotrec 2018). Developed economies are now well advanced in developing national strategies and programs for these technological and scientific innovations. As Bruno et al. (2019, p. 7) note, "The disruptions caused by the formation of Industry 4.0 in the next 10-15 years will completely change the structure of the global economy."

The WEF (2018, p. 12) reports that the world of work is undergoing dramatic change as automation (particularly robotics), AI, and other new technologies develop at an unprecedented rate. This is significantly impacting industry as well as the jobs, tasks, and skills required. Indeed, the future "employment landscape" will dramatically change because of the increasing rate of computerization and AI (Bruun and Duka 2018). It is not just routine tasks that will be impacted. Increasingly, computers are handling more complex and variable data, which means that jobs that were thought to be "uncomputerizable" are being affected; for example, in diagnostic 
tasks in health care; and impartial decision making in fraud detection, deciphering, and contract or patent law research. Bruun and Duka (2018, p. 1) report that based on current estimates and research, "robotic labor will increasingly substitute human labor en masse across most sectors of the economy."

Traditionally the world of work has provided social and economic foundations for stability and social advancement for most families and communities (Marope et al. 2015). Work and employment provide social status and standing in communities for many people, particularly in Western society. More importantly, people use their income to meet their basic needs (affordable housing in healthy environments, good food, and high-quality health care). Human beings, as social beings, are then able to contribute to the broader society.

Job insecurity, high levels of informal employment, and long-term unemployment have an adverse effect on an individual's health and well-being. Moreover, at the macro level there is a strong correlation between high levels of stable employment in a society and better individual and public health (Prainsack and Buyx 2018). The dignity of work brings social cohesion and contributes a sense of social identity for the individual while a loss of work and income for an individual can bring a loss of personal identity and a meaning in their life, and fracture social cohesion.

Bruun and Duka (2018) pose two key questions about the impact of AI on employment: "How will our society be able to accommodate the displacement of a large percentage of its workforce within a generation or two?"; and "how will these shifts affect social cohesion?" (Prainsack and Buyx 2018, p. 5). Without intervention, these developments are likely to lead to "ever-more fractured, divided societies" (Prainsack and Buyx 2018, p. 287). This is exacerbated by the COVID-19 pandemic. It is therefore more urgent than ever to rethink elements and principles of what should be a good standard of work and living for all. This has implications for the content of, and approaches to, education and school, and for the characteristics of a learning society.

\subsubsection{The Environment and Climate Change}

Climate change is another major disruption that will also affect jobs, livelihoods, and the way people live particularly in Asia and the Pacific. This in turn will impact on education and schooling.

Climate change is happening harder and faster than predicted. The last 5 years are the warmest on record and natural disasters are happening more frequently and more intensely. Biodiversity loss and the rate of extinction is alarming (WEF 2020a). The UN Secretary-General Guterres has highlighted that so far, the world's efforts to stop climate change has been "utterly inadequate" and is warning that we are nearing the "point of no return" (Parra and Jordans 2019).

Just before the onset of the global health pandemic, respondents to the WEF's Global Risks Perception, listed climate change and related environment issues as among the top five risks in terms of likely future scenarios (WEF 2020a). Rising sea 
levels, more frequent forest fires, glacial ice melts, and disappearance of coral reefs and species extinctions "is our reality right now, it will get worse, but it's already very, very, bad" (McKibben 2020, p. 4).

The results of the WEF Global Risks survey provide a useful guide to the disruptive forces that our communities and countries are dealing with, including economic, environmental, geopolitical, technological, and societal concerns.

In terms of climate change, according to the World Bank, the broader East Asia and Pacific region is the largest contributor to greenhouse gas emissions, accounting for one-third of the world's carbon dioxide emissions and $60 \%$ of its coal consumption. Curbing emissions in the region is critical to advancing the global climate change agenda (World Bank 2020c). While there is a fall in greenhouse gas emissions and pollution in major cities suffering the worst effects of COVID-19, these changes have been chaotic and unplanned mainly due to the disruption to industrial production and energy use (Lombrana and Warren 2020). The concern is that the comeback of economic activity might quickly wipe out any positive impact on the environment that has occurred due to reduced economic activity because of the health pandemic.

Currently, the world is particularly focused on the risk of COVID-19. This pandemic is testing resilience, but as nations around the world give attention to recovery, it is to be hoped that they will not lose sight of climate risk, because climate change planning is for the long term. Downplaying it in the short to medium term is not a viable option. As McKibben (2020) puts it, physics does not compromise and will not wait.

\subsubsection{Education and Learning}

In terms of formal learning, closing schools and tertiary institutions, including technical and vocational education and training (TVET) institutes, and adult learning education (ALE) institutions, have been part of the mitigation strategy for almost all countries in the world. Students have adapted to digitized and online learning as well as a modified form of face-to-face learning as restrictions ease. However, there is a concern that online and digitized learning will not compensate for the learning lost when schools and education institutions return to "normal" times, and that there are inequalities in terms of which learners get access to the internet (Magnuson 2020). For example, in Southeast Asia there is a significant digital divide in terms of access to and use of internet devices. Countries such as Singapore have $80 \%$ digital internet penetration whereas Indonesia has 56\% and Viet Nam 38\% in 2019 (Jalli 2020).

The rollercoaster of closure and opening, and the semi-opening of schools and tertiary institutions, will have long-term consequences for individuals, communities, and societies. As Magnuson (2020) notes, it will be the most vulnerable who are affected the most, such as, for example, students from poor and marginalized households. In the short term, the impact may well be that some students will not be able to read and write. This has long-term consequences for lifelong learning, especially for those young people who drop out of school, or suffer a decline in 
learning, who will "face lower lifetime productivity and earnings" (World Bank 2020b; OECD 2020a). Gillard (2020), the Director of Global Education Partnerships, stresses that a lifetime of poorer learning outcomes and lower future earnings is a great risk, particularly for millions of children in developing countries including in Asia and the Pacific.

In a recent policy briefing on education and COVID-19, the UN Secretary General Guterres sounded an alarm, saying that we must all take action to try and prevent this learning crisis from becoming a generational catastrophe that could waste untold human potential, undermine decades of progress, and exacerbate entrenched inequalities (UN 2020). Disruption to TVET skills and training; for example, a reduction in apprenticeships in industries such as tourism, hospitality, aviation, and leisure services, where demand is at an historic low, will hamper the eventual recovery of economies and could well lead to skills shortages in some areas (OECD 2020b).

The Asian Development Bank has prepared a guidance note on education in Asia and the Pacific, post COVID-19 (ADB 2021). The note examines approaches to coping with COVID-19 disruptions with regard to kindergarten to grade 12 (or K-12) school education, TVET and disruptions to job markets, and higher education. It also outlines possible scenarios for re-imagining education and training after COVID-19. The guidance note presents an initial set of issues and suggestions to initiate a discussion on transformational changes in education as a result of the challenges that have had to be confronted due to the global COVID-19 health pandemic, with particular reference to countries in Asia and the Pacific.

The difficult problems faced in this age of disruption may seem insurmountable, especially when viewed through the lens of a global health pandemic during a period of lockdown. However, as McKibben (2020) says reassuringly, society has faced "problems from hell" before and worked out successful solutions. The World Bank (2020b, p. 7) proposes that societies now have a real opportunity "to build back better, and they should seize it." In addition, the UN Secretary-General has highlighted the opportunity to reimagine education and build systems that are more forward-looking, inclusive, flexible, and resilient (UN 2020). The changes brought about by the pandemic provides an opportunity to build on those systems for lifelong learning that safeguard quality and inclusiveness.

\subsection{The COVID-19 Era: Auguring Prospects for the Biggest Revolution in Learning}

\subsubsection{COVID-19}

The COVID-19 health emergency has and is having a profound effect on communities and societies, including the vast and diverse Asia and Pacific region (World Bank 2020c). Lockdowns and travel restrictions, which have been constraining the movement of people at the local, regional, national, and international levels, are 
impacting labor markets and the supply of goods and services (UN-Habitat 2020). The depth and duration of the pandemic is uncertain, while "pandemic fatigue" is occurring as communities prepare for what is often referred to as the "new normal".

In a recent webinar, Guevara (2020) stressed that the COVID-19 pandemic has exposed the interconnectedness of multiple crises, making visible existing health, economic and educational inequalities in the Southeast Asian region.

In terms of economic growth, countries that rely heavily on tourism are particularly vulnerable (Cambodia, Thailand) as are countries that carry high levels of debt (the People's Republic of China, Malaysia, Thailand, Viet Nam). Commentators note that the current uncertainty is likely to cause a prolonged recession and hamper recovery. The economic impact of the virus in the Asia and Pacific region is only beginning to be felt, while the effects will last for years to come (Massola 2020; Oxford Economics 2020; World Bank 2020a).

\subsubsection{Re-imagining Lifelong Learning}

Education policy makers and researchers, and other informed commentators, are referring to the COVID-19 pandemic as being a catalyst for the biggest revolution in education, a once in a lifetime opportunity for re-imagining education and schooling, and the notion of learning societies (OECD 2020a; Lim-Lange 2020; UN 2020). Lifelong learning systems such as learning communities, learning cities, and learning regions (under the umbrella of a learning society) are an important part of this revolution. There is also a growing body of knowledge on how to develop and sustain a learning city. This does not depend on a one-size-fits-all model but is shaped by a city's location and political orientation (Boshier 2018). The model can also be adjusted to accommodate the specific characteristics of rural and regional communities.

Charungkaittikul (2020) notes that the importance of lifelong learning and learning societies has been widely recognized for a considerable time in Asia and the Pacific. Her analysis of the lifelong learning policy and practices of selected countries within the region provide growing convincing evidence that policy makers and national experts recognize the vital importance of lifelong learning to develop sustainable futures. She specifically refers to countries such as Australia, the Republic of Korea, Singapore, and Thailand-all of which have made significant progress to incorporate lifelong learning as part of their education systems, with the specific measures adopted varying from country to country. Charungkaittikul refers to the importance of skills recognition in Australia, the National Lifelong Learning Promotion Plan in the Republic of Korea, alternative education in Myanmar, and teacher development programs through e-learning in the Philippines. In addition, there is a potential network of "learning cities for a post-COVID-19 era" project in Thailand, which the Office of Non-Formal and Informal Education is considering in 20 provinces that have the highest number of people affected by the health pandemic (Omas 2020). As pointed out by Charungkaittikul, 
There is a clear, shared recognition across Asia-Pacific countries that the need and demand for lifelong learning will continue to grow, as will the importance of terms such as learning society, learning region, learning cities, and learning communities. While specific policy priorities to support lifelong learning are likely to depend on the context, there is a growing consensus about the importance of developing learning societies. (Charungkaittikul 2020, p. 117)

\subsubsection{Transforming the Formal Education System}

The formal education system is having to transform rapidly because of COVID-19, and countries in Asia and the Pacific are leading the way. For example, Tam and Al-Azar (2020), in a WEF blog, highlight positive trends that could result in future transformations, which include the following:

(i) The blooming of innovations. In some countries with strong 5G digital networks, policy makers and practitioners are taking real advantage of new modes of learning. For example, in the People's Republic of China, some 120 million Chinese students have been sitting in front of their television sets, learning through national broadcasts. Students in Hong Kong, China have been learning on digital apps since February 2020 (Lim-Lange 2020).

(ii) Public-private partnerships can grow in importance. The World Bank cites examples from the People's Republic of China, where stakeholders from different sectors (media, industry professionals, and government) have come together to provide an array of educational assets (such as videos, book chapters, assessment tools) that can be used by students. While the initiatives so far are limited in scope, the pandemic could pave the way for much larger-scale, cross-industry coalitions to be formed around a common educational goal.

There is an opportunity provided by the response to the crisis to innovate and build education systems that are stronger and more equitable than they were before. As a result of the health pandemic, "Many actors—parents, teachers, mass media, government and others-will have changed their perception about their role in the education process" (World Bank 2020b, p. 32). For example, parents will have a better understanding of the need to work jointly with schools to foster the education of their children. The innovations developed in response to the health pandemic have shown what is possible when countries focus on the most effective and equitable approaches to close learning gaps for all children.

Societies have a real opportunity to "build back better" and to use the most effective crisis recovery strategies as a basis for long-term improvements. Hence, they should seize the opportunity (World Bank 2020b). On the other hand, a real threat is that the digital divide could widen as a result of the health pandemic, and this is a major issue that needs to be decisively and constructively addressed (Tam and Al-Azar 2020). Although this is not inevitable, it must be borne in mind that currently, only $60 \%$ of the world's population is online and access is very uneven across the countries of Asia (Jalli 2020). 


\subsection{Conclusions}

Throughout Asia and the Pacific, an increasing emphasis is occurring regarding the importance of learning societies. But how are such learning societies best configured and powered in an age of disruption?

(i) Create a framework articulating principles and values of lifelong learning. One way is to create a framework that provides underlying principles and values for the best way societies can be organized, based on the well-documented view that learning is an important catalyst for change and improvement. Key principles and values include attention to policy development; more responsive governance with adaptive institutional structures; multi-stakeholder partnerships and collaboration, rather than a tendency for just the private sector to be a key actor; and civil engagement as a key element, especially building bridges between different sectors of society. It is also important to have a recognition of how this concept will need to be continually adapted in place-based contexts. In a continually changing environment, measurement and evaluation should focus on learning and adaption, not just evaluation.

(ii) Enable lifelong learning to tackle key factors of disruption globally. There will be increasing disruption from those factors identified by the WEF (2020a) as important matters that countries will need to deal with, e.g., climate change and the environment; economic change (especially due to the ramifications of Industry 4.0); technological developments; possible future health pandemics; and geopolitical change (including that involving the need for conflict resolution).

(iii) Align with the UN Sustainable Development Goals. Any framework developed must also align with the UN Sustainable Development Goals and with Quality Education and Sustainable Cities and Communities. UN-Habitat (2017) highlights the importance of the linkages between urban, peri-urban, and rural areas; and of adopting an integrated planning approach at regional and national levels, inclusive of rural and regional communities.

(iv) Reimagine formal education to further stimulate lifelong learning. Learning society practitioners stress the importance of building a culture of learning within a community, whether this be at the neighborhood level, within a larger geographic area, or online. As well as re-imagining formal education, the involvement of people from vulnerable and disadvantaged groups is vital. The ways that countries throughout Asia and the Pacific have responded to the COVID-19 pandemic provides many examples of how these communities have been able to be very responsive in working with the most vulnerable.

(v) Asian economies should foster a learning society. There is a growing consensus on the importance and need to continue developing learning societies in Asia. In Asia and the Pacific, the Republic of Korea provides an advanced model that could be adopted by others, such as its National Lifelong Learning Policy, which translates to plans in at least 46 cities with practical 
outcomes in neighborhoods, and the vision of a learning center within $10 \mathrm{~min}$ of where people live.

(vi) Enable lifelong learning to become resilient to all types of shocks and disruptions. The questions posed by Bruun and Duka (2018) about whether societies will be able to accommodate disruptions and the displacement of the workforce due to AI, and how the major shifts of technological change affect social cohesion, apply to all areas of disruption. Now is an opportune time to consider how best to provide a good standard of living for all, and this starts by considering how the principles and values of learning societies can be most effectively applied to address major disruptions in order to build the next normal.

\section{References}

Asian Development Bank (ADB). 2021. COVID-19 and education in Asia and the Pacific. Guidance Note. Manila.

Boshier, R. 2018. Learning cities: Fake news or the real deal? International Journal of Lifelong Education 37 (4): 419-434.

Bruun, E.P., and A. Duka. 2018. Artificial intelligence, jobs and the future of work: Racing with the machines. Basic Income Studies 13 (2): 1-15.

Bruno, S., et al. 2019. Outlines of the context for Industry 4.0. In Understanding industry 4.0: AI, the internet of things, and the future of work. Bingley: Emerald Publishing Limited.

Charungkaittikul, S. 2020. Lifelong learning in Asia and the Pacific: policy implications. In Proceedings of Adult Education in Global Times: An International Research Conference, 116-121. Vancouver: University of British Columbia. https://edst-educ.sites.olt.ubc.ca/files/ 2020/06/aegt_proceedings_upload.pdf.

Delors, J., et al. 1996. Learning: The treasure within. Report to UNESCO of the International Commission on Education for the Twenty-First Century. Paris: UNESCO.

Elfert, M. 2015. UNESCO, the Faure Report, the Delors Report, and the political utopia of lifelong learning. European Journal of Education 50 (1): 88-100. https://doi.org/10.1111/ejed.12104.

Envirotrec. 2018. Industry 4.0: A view from the OECD. Canadian Environmental Test Research and Education Centre. https://www.envirotrec.ca/2018/industry-4-0-a-view-from-the-oecd/.

Faris, R. 2008. What are learning communities? Focus on knowledge and learning. Victoria: Social Planning and Research Council of British Columbia.

Faure, E., et al. 1972. Learning to be. The world of education today and tomorrow. Paris: UNESCO/Harrap.

Gillard, J. 2020. Millions of children may never return to school after lockdown. The Sydney Morning Herald, August 4. https://www.smh.com.au/national/millions-of-children-may-neverreturn-to-school-after-lockdown-20200730-p55gs4.html.

GIM. 2020. Sustainability trends report 2020. https://str2020.generationim.com/chapters/introduct ion\#entry-5083.

Guevara, J.R. 2020. Adult learning crisis and the "new" normal. Paper presented in an Adult Learning Australia Webinar Session. 29 July 2020, Melbourne.

Harari, Y.N. 2015. Homo deus: A brief history of tomorrow. London: Penguin Random House.

Jalli, N. 2020. Lack of internet access in Southeast Asia poses challenges for students to study online amid COVID-19 pandemic. The Conversation, March 17. https://theconversation.com/ lack-of-internet-access-in-southeast-asia-poses-challenges-for-students-to-study-online-amidcovid-19-pandemic-133787. 
Kearns, P. 2015. Learning cities on the move. Australian Journal Adult Learning 55 (1): 153-168. Lim-Lange, C. 2020. Commentary: COVID-19's education revolution - where going digital is just half the battle, April 19. https://www.channelnewsasia.com/news/commentary/covid-19-corona virus-education-digital-revolution-transformation-12650974.

Lombrana, L.M., and H. Warren. 2020. A pandemic that cleared skies and halted cities isn't slowing global warming. https://www.bloomberg.com/graphics/2020-how-coronavirus-impacts-climatechange/.

Longworth, N., and M. Osborne. 2010. Six ages towards a learning region-A retrospective. European Journal of Education 45 (3): 368-401.

Maclean, R., and V. Ordonez. 2007. Work, skills development for employability and education for sustainable development. Educational Research for Policy and Practice 6 (2): 123-140.

Magnuson, P. 2020. COVID-19: Building a sustainable and just future for all. https://thelifelo nglearningblog.uil.unesco.org/2020/05/22/covid-19-building-a-sustainable-and-just-future-forall/\#more-736.

Marope, P., B. Chakroun, and K. Holmes. 2015. Unleashing the potential: Transforming technical and vocational education and training. Education on the Move. https://unesdoc.unesco.org/ark:/ 48223/pf0000233030.

Massola, J. 2020. Why some countries are surging and others slumping in pandemic. The Age. Melbourne, Fairfax.

McKibben, B. 2020. FALTER: Has the human game begun to play itself out?. New York: Henry Holt \& Co.

Organisation for Economic Co-operation and Development (OECD). 2020a. Education and COVID-19: Focussing on the long-term impact of school closures. OECD Policy Response to the Coronavirus (COVID-19) - Tackling Coronavirus: Contributing to a Global Effort. 29 June 2020. http://www.oecd.org/coronavirus/policy-responses/education-and-covid-19-foc using-on-the-long-term-impact-of-school-closures-2cea926e/.

OECD. 2020b. VET in a time of crisis: Building foundations for resilient vocational and training education systems. OECD Policy Responses to Coronavirus (COVID-19). 6 May 2020. http://www.oecd.org/coronavirus/policy-responses/vet-in-a-time-of-crisis-buildingfoundations-for-resilient-vocational-education-and-training-systems-efff194c/.

Omas, R.A. 2020. Expert reflections. https://www.dvv-international.de/en/our-work/reaction-to-cor ona-pandemic/expert-reflections.

Oxford Economics. 2020. The economic impact of COVID-19 on Asia Pacific. Singapore. https:// www.undp.org/content/undp/en/home/librarypage/crisis-prevention-and-recovery/the-socialand-economic-impact-of-covid-19-in-asia-pacific.html.

Parra, A., and F. Jordans. 2019. UN chief warns global warming "point of no return" is hurtling toward us. Science Alert. https://www.sciencealert.com/un-chief-warns-global-warming-s-pointof-no-return-is-hurtling-toward-us.

Pascal International Observatory. The UNESCO Global Network of Learning Cities welcomes 55 new member cities from 27 countries. http://pascalobservatory.org/pascalnow/pascal-activities/ news/unesco-global-network-learning-cities-welcomes-55-new-member-cities.

Prainsack, B., and A. Buyx. 2018. The value of work: addressing the future of work through the lens of solidarity. Bioethics 32 (9): 585-592.

Samantekt, H.Ó. 2015. UNESCO: Education for sustainable development 2005-2014. https://men ntuntilsjalfbaerni.weebly.com/uploads/6/2/6/2/6262718/unesco_5_pillars_for_esd.pdf.

Tam, G., and D. Al-Azar. 2020. 3 Ways the coronavirus pandemic could reshape education. https://www.weforum.org/agenda/2020/03/3-ways-coronavirus-is-reshaping-educat ion-and-what-changes-might-be-here-to-stay/.

United Nations (UN). 2020. Policy briefing: Education during COVID-19 and beyond. https://www. un.org/sites/un2.un.org/files/sg_policy_brief_covid-19_and_education_august_2020.pdf.

UN-Habitat. 2017. Implementing the new urban agenda by strengthening urban-rural linkages: Leave no one and no space behind. https://unhabitat.org/implementing-the-new-urban-agendaby-strengthening-urban-rural-linkages. 
UN-Habitat. 2020. Human mobility across the urban-rural continuum in the time of COVID-19. Policy, Legislation and Governance Webinar Series. http://urbanpolicyplatform.org/policy-legisl ation-and-governance-webinar-series/\#1593014660107-40c493cf-3825.

United Nations Educational, Scientific and Cultural Organization (UNESCO). 2015. Education 2030, Incheon Declaration: towards inclusive and quality education and lifelong learning for all. https://iite.unesco.org/publications/education-2030-incheon-declaration-framework-act ion-towards-inclusive-equitable-quality-education-lifelong-learning/.

UNESCO. 2020. Education in a post COVID world: Nine ideas for public action. Paris: International Commission on the Future of Education, UNESCO Education Sector. https://unesdoc.unesco.org/ ark:/48223/pf0000373717/PDF/373717eng.pdf.multi.

UNESCO Institute for Lifelong Learning (UIL). 2015. Members of the UNESCO Global Network of Learning Cities. https://uil.unesco.org/sites/default/files/doc/lifelong-learning/cities/list-of-mem bers-unesco-gnlc-uil.pdf.

Wheeler, L., et al. 2013. Learning as a driver for change. Sydney: Australian Centre of Excellence for Local Government, University of Technology. https://opus.lib.uts.edu.au/handle/10453/42056.

World Bank. 2020a. Global economic prospects. Washington, DC. https://openknowledge.worldb ank.org/handle/10986/33748.

World Bank. 2020b. The COVID-19 pandemic: Shocks to education and policy responses. Washington, DC. https://openknowledge.worldbank.org/handle/10986/33696.

World Bank. 2020c. The World Bank in East Asia Pacific: Overview. https://www.worldbank.org/ en/region/eap/overview.

World Economic Forum (WEF). 2018. Eight futures of work: Scenarios and their implications. https://www.weforum.org/whitepapers/eight-futures-of-work-scenarios-and-their-implications.

WEF. 2020a. The global risks report 2020. http://www3.weforum.org/docs/WEF_Global_Risk_R eport_2020.pdf.

WEF. 2020b. Why this moment could be decisive for tackling climate change: Report. https:// www.weforum.org/agenda/2020/07/how-covid-19-could-spark-climate-change-recovery-sustai nability/.

Wood, J. 2020. Why this moment could be decisive for tackling climate change: Report. https://www.weforum.org/agenda/2020/07/how-covid-19-could-spark-climate-changerecovery-sustainability/.

Yang, J., and R. Yorozu. 2015. Building a learning society in Japan, the Republic of Korea and Singapore. Hamburg: UNESCO UIL. https://uil.unesco.org/lifelong-learning/policies-database/ building-learning-society-japan-republic-korea-and-singapore.

Yiannouka, S. 2020. Building the future of education in a post-pandemic world. In Education disrupted, education reimagined: Thoughts and responses from education's frontline during the COVID-19 pandemic and beyond. Doha: WISE. https://www.wise-qatar.org/building-the-futureof-education-in-a-post-pandemic-world/. 
The opinions expressed in this chapter are those of the author(s) and do not necessarily reflect the views of the Asian Development Bank, its Board of Directors, or the countries they represent.

Open Access This chapter is licensed under the terms of the Creative Commons Attribution-NonCommercial 3.0 IGO license (http://creativecommons.org/licenses/by-nc/3.0/igo/) which permits any noncommercial use, sharing, adaptation, distribution and reproduction in any medium or format, as long as you give appropriate credit to the Asian Development Bank, provide a link to the Creative Commons license and indicate if changes were made.

Any dispute related to the use of the works of the Asian Development Bank that cannot be settled amicably shall be submitted to arbitration pursuant to the UNCITRAL rules. The use of the Asian Development Bank's name for any purpose other than for attribution, and the use of the Asian Development Bank's logo, shall be subject to a separate written license agreement between the Asian Development Bank and the user and is not authorized as part of this CC-IGO license. Note that the link provided above includes additional terms and conditions of the license.

The images or other third party material in this chapter are included in the chapter's Creative Commons license, unless indicated otherwise in a credit line to the material. If material is not included in the chapter's Creative Commons license and your intended use is not permitted by statutory regulation or exceeds the permitted use, you will need to obtain permission directly from the copyright holder.

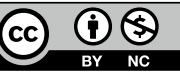

